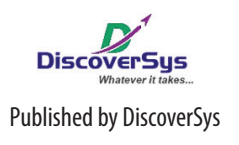

Published by DiscoverSys

\section{Perceptions of patients and providers on the use of acupressure services at Public Health Centres, Tabanan District, Bali}

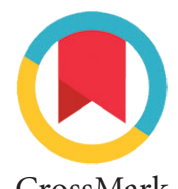

CrossMark

I Made Sukawinaca, ${ }^{1,2 *}$ Komang Ayu Kartika Sari, ${ }^{2,3}$ | Made Ady Wirawan²,4

\title{
ABSTRACT
}

Background and purpose: Acupressure services are available at some public health centres (PHCs) in Bali, but the service utilisation remains low. The purpose of this study is to explore the perception of patients and service providers on the use of acupressure services at PHC in Tabanan.

Methods: This study used a qualitative design based on observation and in-depth interviews with 13 informants consisting of patients, health service practitioners, head of PHC and program manager at Tabanan Health Office. The informants were chosen purposively and the data were analysed thematically.

Results: There were different perceptions regarding the benefits of acupressure services between patients utilising the services and those who had not. Patients who had undergone acupressure demonstrated positive perception of the service. Acupressure services are considered to be effective in dealing with patient complaints, have no side effects, and patients reported being satisfied with the services provided by the PHC. Patients who did not utilise acupressure services, view acupressure as an ineffective therapy with potential side effects that may endanger their health. These patients experienced trauma from similar massage techniques. Service providers lamented the absence of government support in the form of local regulations that would enable them to access funding, increase human resources and facilitate promotion of the services.

Conclusions: Patient perceptions of acupressure services still vary, with some contraints in the implementation that consist of local regulation, operational fund and human resources. Acupressure services still require synergy between central and local government policies to support its implementation.

Keywords: acupressure, traditional medicine, primary health care, service utility.

Cite This Article: Sukawinaca, I.M., Sari, K.A.K., Wirawan, I.M.A. 2018. Perceptions of patients and providers on the use of acupressure services at Public Health Centres, Tabanan District, Bali. Public Health and Preventive Medicine Archive 5(2): 124-128. D0I:10.15562/phpma.v5i2.26

${ }^{1}$ Tabanan General Hospital,

2Public Health Postgraduate Program Udayana University, ${ }^{3}$ Department of Community and Preventive Medicine Faculty of Medicine Udayana University, ${ }^{4}$ School of Public Health Faculty of Medicine Udayana University

*Correspondence to:

I Made Sukawinaca, Tabanan General Hospital

supernaca34@gmail.com

\section{INTRODUCTION}

The implementation of traditional medicine forms, including acupressure, are often integrated and synergised with modern medicine in health facilities in order to resonate with the changing needs of a society. ${ }^{1,2}$ The official synergisation of traditional and modern medicine within PHCs is designed to improve the quality of service, ensure monitored service provision of such services by providers and to protect patient health rights. ${ }^{1}$ Bali Province is one of the regions that, rather than denigrating traditional healing methods, seeks to integrate acupressure services at PHCs in the province. Of the 120 PHCs in Bali Province, ${ }^{3} 10$ new PHCs provide these services, two in particular being located within the Tabanan District, namely PHC Tabanan III and PHC Baturiti I. ${ }^{4}$

The utilisation of acupressure services in both PHCs is still low. Since January 2016 in one month on average only 4-5 patients have utilised the service. ${ }^{5,6}$ Based on this low uptake, this research on perceptions or views of patients on the use of acupressure services in PHCs in Tabanan District was carried out. Findings from this research will provide input to government institutions, especially the local health office, on appropriate program implementation and roll out.

\section{METHODS}

This qualitative study used a despciptive approach to explore the perception of patients and service providers related to the utilisation of acupressure services at PHCs. This research was conducted from February to March 2017. Data was collected through in-depth interviews involving 13 informants consisting of four patients who utilised acupressure services, four patients who did not use acupressure services, two service providers, two managerial heads of the PHCs, as well as one traditional medicine coordinator at the Tabanan Health Office. The informants were chosen purposively according to a predetermined inclusion criteria. Patients who have used the service were those who have accessed the services at least twice a month. Patients who have not accessed the service were those who have previously received information about the service but have not utilised it. The results were analysed thematically through code and theme 
identification. This research has been approved by the Human Research Ethic Committees of Faculty of Medicine, Udayana University/ Sanglah Hospital Denpasar.

\section{RESULTS AND DISCUSSION}

Based on the results of analysis, it was found that individual perceptions of the acupressure service greatly affected the utilisation. Those who had utilised the services perceived the service to be beneficial, while those who questioned its benefits were disinclined to access the services. The analysis also found barriers to service delivery. The results of the analysis are presented as follows.

\section{Positive perceptions of acupressure services}

All patients who had used acupressure services perceived that acupressure services are effective, have no adverse health effects, and they were satisfied with the service provided by the PHCs. As the below informants explained:

"For acute headaches and migraines it was helpful. I felt much better after the procedure. I also didn't feel any side effects." (Informant utilising acupressure A2).

"Hmm, it wasn't how I imagined it to be, as I had heard it would be painful...the positive effects were felt immediately... the practitioner was very skilled... and it was free..." (Informant utilising acupressure A4).

The results of this study are in accordance with previous qualitative research which found that patients perceive acupressure as an effective form of traditional medicine, had no detrimental side effects, increased body stamina, reduced various complaints, the experience was not traumatic and qualified health professionals who performed the service helped patients feel a sense of belief in the benefits. ${ }^{7-10}$ Previous clinical studies conducted in Taiwan, the United States and Iran have proven that acupressure is one of the most effective acupuncture methods to overcome various illness, nausea, vomiting, decreased anxiety, increased corporeal comfort, improved sleep quality, addressed shortness of breath, fatigue and insomnia. ${ }^{11-14}$ Acupressure method has also been proven to address pain symptoms by up to $74.4 \% . .^{15}$

Acupressure services have been permitted and synchronised by the government because they are safe, non-intrusive, easy, cheap, aligned with belief systems prevailing in the community, and are conducted in health facilities to ensure their safety ${ }^{16}$ The promotion of such programs needs to be carried out emphasising the service benefits so as to encourage a paradigm shift and increase patient uptake.

The results of the analysis also found that patients who had used acupressure services had experienced ongoing disease or complaints that had disrupted daily activities, and been non-responsive to modern medical treatment. Patients with lower back pain, migraine, pinched nerves, cough, runny nose, morning sickness, and sleeping difficulty were some of the complaints of patients seeking acupressure services, as described below:

"The migraines I was experiencing were unbearable."(Informant utilising acupressure A2).

"I was suffering from bad insomnia, sinus and cough, and frequent dizziness...no medication seemed to address it...this went on for about 3 months." (Informant utilising acupressure A4).

The results of this study are consistent with several studies which found that patients with cancer, low back pain (LBP), as well as some complaints of discomfort related to pregnancy tend to utilise acupressure services. ${ }^{7-18}$ Acupressure services need to be promoted so that it can be adopted by the wider community as an alternative treatment as well as complementary therapy in addition to modern medicine at a health facility.

\section{Negative perceptions of acupressure services}

All patients who did not use acupressure services had experienced trauma with massage techniques. The previous traumatic experiences that patients had using massage techniques impact negatively on the patient's view of acupressure services, such as quotes from informants who did not use the acupressure service below:

"I am considering it but I am afraid, perhaps traumatised. After having a massage once when I should have felt much better I felt terrible." (Informant not utilising acupressure B4).

The results of this study are in accordance with qualitative research conducted in the United Kingdom which showed that previous experience in using traditional medicine will influence the decision of the patient in the future. ${ }^{19}$ Positive experiences experienced by patients in childhood in utilising traditional medicine influence the decision to reutilise the service. ${ }^{20}$ It has been shown that health promotion should include positive testimony from patients who have recovered 
through the assistance of acupressure services. The results of previous qualitative research conducted in Surabaya showed that promotion through advertising by including testimony from patients who have been cured through utilising traditional medicine in television and printed media, positively affects the public perception of traditional medical services. ${ }^{21}$

Some patients did not use acupressure services because they viewed acupressure as an ineffective therapy and have side effects that can endanger health, as echoed by the respondent below:

"....it is not that I don't want to get better, it is just that I got worse... when I feel achy in the future I will just go to the doctor for medicine." (Informant not utilising acupressure B4).

The results of this study align with several qualitative studies indicating that patients do not use acupressure services because they view it as an ineffective therapy that has potentially dangerous side effects. ${ }^{7-9}$ Results of previous clinical trials conducted in India and Taiwan also showed that acupressure therapy was not always successful, in overcoming pain and reducing the incidence of nausea in urological endoscopy and lumbar spine postoperative care. ${ }^{22,23}$

Negative perceptions of patients who had not utilised the services are also associated with service waiting time. Baturiti I PHC offered acupressure services every Friday, while Tabanan III PHC, every Monday and Friday only. Interviews with patients who did not use the service showed that the limited availability influence the service utilisation. One informant lamented on the lack of flexibility to access the services:

"If possible don't only offer it on Monday or Friday, it should be made available on a number of weekdays."(Informant not utilising acupressure.B4).

The results of previous research indicate that service access greatly determines the utilisation of services in PHC. ${ }^{24,25}$ Other research conducted by Sumanti et al in Gianyar, Bali found that the service provision hours or the working hours of health providers conflicted with that of potential adopters, thereby reducing the participation of the community in utilising services at the PHC. ${ }^{26}$ Additional service days would help address the lack of service uptake.

The results of this study indicate that the negative perception of patients on acupressure services greatly affects service uptake in both PHC. Further investigation into beliefs and the influence of the power of suggestion would feed into the findings of this study.

\section{Barriers in the implementation of acupressure services at PHC}

During the study there was only one trained acupressure service provider in each PHCs. Evidently, barriers in the implementation of acupressure services include the paucity of qualified human resources in conjunction with the burden of numerous work duties, such as intimated by informants below:

"It would be good if others were also trained... so it is not just me that is capable... because often times I need to leave the clinic for home visits, so patients seeking acupressure are not attended to." (Service provider C2).

"It is clear that the fact there is only one qualified practitioner impacts upon patient uptake." (Head of PHC.IK.1).

The results of this study resonate with the results of several previous studies which show that the lack of skilled personnel and in addition to increasing the workload of health workers greatly affects the implementation of a health care program..$^{27-29}$ Human resource management should be designed to improve the quality of services so as to increase patient satisfaction. ${ }^{30}$ The dearth of trained acupressure personnel can be addressed through the addition of newly up-skilled personnel and through putting in place interventions to address heavy workload and staff task duplication.

The results of interviews with service providers also indicate that acupressure services at PHC in Tabanan District did not run optimally due to financing factors i.e. no specific operational funds for service promotion and incentives for acupressure service providers, as reflected in the below statements:

"There are challenges in rolling out this initiative... internal issues such as lack of funding... there needs to be specifically allocated funding....for example, to help with promoting the program." (Head of PHC.IK2).

"We receive no compensation. It would be nice to have some form of recognition. All other services receive this kind of respect, we should too." (Service provider.C2).

The results of this study are consistent with findings from previous studies showing that health budgets allocated for direct activities such as health 
counselling, community empowerment, disease prevention, and other direct programs are minimal, compared to indirect activities such as managerial or coordination activities. ${ }^{31}$ Increased commitment from the government in financing individual health programs is undeniably needed. Programs can run optimally if supported by the government, for example, in the provision of incentives for service delivery officers and compensation.

The results of interviews with service providers indicate that the absence of local regulations governing acupressure services at PHC was also a major factor hampering the implementation of services, such as reflected below:

"How can we actually promote the program when there are no regional regulations addressing it. Once this is in place, then we can move ahead."(Head of PHC.IK.2).

"Quite possibly, aside from the human resource issue, an obstacle includes the lack of Department of Health regulation." (Head of PHC.IK.1).

The results of this study are comparable with the results of previous research indicating the lack of preparedness or support of policy makers in issuing technical policy or regulation regarding service provision. ${ }^{32}$ The Health Act No.36 / 2009 (3) and (6), states that the provincial and local governments are responsible for the application of traditional health services in health facilities. ${ }^{33}$ Presidential Regulation No. 103 of 2014 guarantees and regulates the integration of traditional health services into all health facilities throughout Indonesia, thus requiring local governments to draft local policies on the provision of traditional health services in their regions. ${ }^{1}$ Moving ahead, regional stakeholders and decision makers need to continue to be lobbied so that local regulations can respond to the issues of limitations in human resources and lack of operational funding.

\section{CONCLUSION}

Patients who use acupressure have a positive perception of the benefits of the treatment, however, those still disinclined view acupressure as an ineffective service, imagining harmful side effects, had experienced past trauma with massage techniques, and complained about the limitation of service provision hours. Constraints faced in the implementation of services include the absence of local regulations on acupressure services in health centres and the lack of operational funds and human resources supporting the implementation of the service.
The synchronisation of acupressure services into current PHCs should greatly be supported by the formulation of central and local government policies addressing implementation and promotion. Application of such policy would help to allow for the provision of operational funds, as well as the allocation of adequate human resources, ensuring that traditional health care systems become wholly integrated and synergised with existing modern medicine care formats in health facilities.

\section{ACKNOWLEDGEMENT}

We would like thanks to all informants and parties who supported the implementation and writing of this research. Special thanks to dr. Wisnu and dr. Kencana as Head of PHC Tabanan III and PHC Baturiti I in Tabanan permitted the authors to conduct this research. The authors would also like to convey thanks to Dr. Pande, Prof. Mangku, and Prof. Adiputra for inputs and suggestions given during the discussion of study findings.

\section{REFERENCES}

1. Ministry of Health of Indonesia. Peraturan pemerintah Nomor 103 [The Ministry of Health of Indonesia Regulation No. 103]. Jakarta: Ministry of Health of Indonesia; 2014.

2. Yuniari S, Suastika, Sri A. Pencarian pelayanan kesehatan pada pengobat tradisional herbal di Kota Denpasar [Health care seeking from the traditional herbal healers in Denpasar City]. Preventive Health Medecine Archive. 2013; 1: 113-119.

3. Bali Provincial Health Office. Profil kesehatan Provinsi Bali 2015 [The 2015 Bali Province Health Profile] Denpasar: Bali Provincial Health Office; 2016.

4. Bali Provincial Health Office. Data pelayanan kesehatan tradisional integrasi tahun 2016 [Data on traditional health services integration in 2016]. Denpasar: Bali Provincial Health Office; 2016.

5. Tabanan District Health Office. Profil UPTD Puskesmas Tabanan III [Tabanan III Public Health Center profile]. Tabanan: Tabanan District Health Office; 2016.

6. Baturuti I Public Health Center. Rekapan jumlah pasien yang dilayani akupresur [The number of patients served acupressure]. Tabanan: Baturuti I Public Health Center; 2016.

7. Wang HM. Cancer patients' experience of combined treatment with conventional and traditional Chinese medicine. Cancer Nursing. 2011; 34: 495-502.

8. Chan K, Siu JY, Fung TKF. Perception of acupuncture among users and nonusers: A qualitative study. Health Market Quarterly. 2016; 33: 78-93.

9. Mollart L, Adams J, Foureur M. Pregnant women 's views on acupressure and other complementary \& alternative medicines (CAM) and being involved in a RCT. Journal of Community Health. 2016; 26: 6.

10. Silva FCB da, Brito RS de, Carvalho JBL de, et al. Using acupressure to minimize discomports during pregnancy. Revista Gaúcha de Enfermagem. 2016; 37: 1-7.

11. Chen H, Chang F, Hsu C. Effect of acupressure on nausea,vomiting,anxiety and pain among post-caesarean section women in Taiwan. The Kaohsiung Journal Medecine Sciences. 2005; 21: 341-350.

12. Dibble SL, Luce J, Cooper BA, et al. Acupressure for chemotherapy-induced nausea and vomiting : a randomized clinical trial. Oncology Nursing Forum. 2007; 34: 813-821. 
13. Gharloghi S, Torkzahrani S, Akbarzadeh A. The effects of acupressure on severity of primary dysmenorrhea. Patient preference and Adherence. 2012; 6: 137-142.

14. Lee EJ, Frazier SK. The efficacy of acupressure for symptom management: a systematic review. Journal of Pain and Symptom Management. 2011; 42: 589-603.

15. Hui V, Ip Y. The use of acupuncture for pain relief in a Chinese hospital clinic. Acupuncture in Medecine. 1999; 17: 101-110.

16. Ministry of Health of Indonesia. Buku pedoman pengobatan tradisional akupresur bagi petugas kesehatan [Traditional acupressure treatment manual for health care workers]. Jakarta: Ministry of Health of Indonesia; 2011.

17. Eaves ER, Sherman KJ, Ritenbaugh C, et al. A qualitative study of changes in expectations over time among patients with chronic low back pain seeking four CAM therapies. BMC Complementary and Alternative Medecine. 2015; 15: $1-10$.

18. Suhami N, Muhamad MB, Krauss SE. Why cancer patients seek islamic healing. Journal of Religion and Health. 2016; 55: 1507-1518.

19. Bishop FL. Why consumers maintain complementary and alternative medicine use : a Qualitative study. The Journal of Alternative and Complementary Medicine. 2010; 16: 175-182.

20. Stöckigt B, Teut M, Witt CM. CAM use and suggestions for medical care of senior citizens : a qualitative study using the world café method. Evidance-Based Complementary and Alternative Medecine. 2013; 1-8.

21. Kristiana L, Agustiya RI, Handayani S, et al. Studi kualitatif kesesuaian pendapatan pasien tentang iklan dengan pelayanan yang diterima dari sarana pengobatan tradisional [Qualitative study of correspondence between patient perception of service advertisement and service provided from traditional health facilities]. Buletin Penelitan Sistem Kesehatan. 2014; 17: 115-123.

22. Agarwal A, Pathak A, Gaur A. Acupressure wristbands do not prevent postoperative nausea and vomiting after urological endoscopic surgery. Canadian Journal of Anaesthesia. 2000; 47: 319-24.

23. Yeh M, Tsou M, Lee B, et al. Effects of auricular acupressure on pain reduction in patient-controlled analgesia after lumbar spine surgery. Acta Anaesthesiologica. 2010; 48: $80-86$.

24. Rumengan DSS, Umboh JML, Kandou GD. Faktor-Faktor yang berhubungan dengan pemanfaatan pelayanan kesehatan pada peserta BPJS kesehatan di Puskesmas Paniki Bawah Kecamatan Mapanget Kota Manado [Factors associated with health care utilization health on BPJS participants in PHC Paniki Mapanget Down District of Manado]. JIKMU, Suplemen. 2015; 5: 88-100.
25. Adriana N, Wulandari LPL, Duarsa DP, et al. Akses pelayanan kesehatan berhubungan dengan pemanfaatan fasilitas persalinan yang memadai di Puskesmas Kawangu Sumba Timur [Access to Health service related to use of antenatal care facilities at the Kawangu Health Centre East Sumba]. Preventive Health Medecine Archive. 2014; 2: $175-180$.

26. Sumanti V, Widarsa T, Duarsa P. Faktor yang berhubungan dengan partisipasi orang tua dalam perawatan kesehatan gigi anak di Puskesmas Tegallalang I [Factors related to parent's participation in child dental health care in Tegallalang I community health centre]. Public Heath and Preventive Medecine Archive. 2013; 1: 7.

27. Noviana N, Setyati S. Pelaksanaan program jaminan kesehatan masyarakat di Kalimantan Selatan [Public health insurance program implementation in South Kalimantan]. Buletin Penelitan Sistem Kesehatan. 2015; 18: 19-28.

28. Manuho, Warouw H. Hubungan beban kerja dengan kinerja perawat dalam pemberian asuhan keperawatan di Instalasi Rawat Inap C1 RSUP Prof.DR.R.D.Kandou Manado [Association of workload with the performance of nurses in the delivery of nursing care in Hospital Inpatient C1 Prof. Dr. R. D. Kandou Manado]. Ejournal keperawatan (e-kep). 2015; 3 (2): 1-8.

29. Vresa Budi Setiawan RDW. Beban kerja subyektif dan obyektif tenaga farmasi rawat jalan di rumah sakit [Subjective and objective workload pharmaceutical worker outpatient in the hospital]. Jurnal Administrasi Kesehatan. 2016; 4: $28-36$

30. Mohamed NS. The impact of human resources management on healthcare quality. International Journal of Management. 2015; 6502: 603-612.

31. Laksmiarti T, Nugraheni P. Analisis kebijakan pembiayaan kesehatan di Kepulauan Aru [Policy Analysis: Health Financing in Aru Island]. Buletin Penelitian Sistem Kesehatan. 2013; 16: 321-329.

32. Geswar RK, Nurhayani B. Kesiapan stakeholder dalam pelaksanaan program jaminan kesehatan nasional di Kabupaten Gowa [The readiness of stakeholders in the implementation of national health insurance program in Gowa Regency]. Jurnal Administrasi dan Kebijakan Kesehatan. 2014; 3: 1-12.

33. Department of Health of Indonesia. Undang-Undang Kesehatan no 36 tahun 2009 [Law no 23 of 2009 on Health]. Jakarta: Department of Health of Indonesia; 2009.

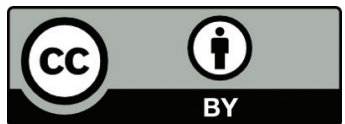

This work is licensed under a Creative Commons Attribution 